\title{
PENGARUH DISIPLIN BELAJAR, KECEMASAN DAN PERHATIAN ORANG TUA TERHADAP HASIL BELAJAR MATEMATIKA SISWA
}

\author{
Aulia Ariski Asmawati ${ }^{1)}$ \\ Sugeng ${ }^{2}$ \\ P.M. Labulan ${ }^{3)}$ \\ ${ }^{1), 2), 3)}$ Program Studi Pendidikan Matematika, Universitas Mulawarman \\ Email: ${ }^{1)}$ auliaariski96@gmail.com ${ }^{2)}$ sugeng@ fkip.unmul.ac.id \\ ${ }^{3)}$ pm_labulan@fkip.unmul.ac.id
}

\begin{abstract}
ABSTRAK
Hasil belajar siswa merupakan salah satu variabel yang banyak diteliti dalam penelitian di bidang pendidikan. Hasil belajar dipengaruhi oleh banyak faktor. Faktor tersebut tidak hanya berupa faktor internal, tetapi juga faktor eksternal. Tujuan penelitian ini adalah untuk mengetahui pengaruh disiplin belajar, kecemasan dan perhatian orang tua terhadap hasil belajar matematika siswa kelas VIII SMP Negeri 27 Samarinda tahun ajaran 2017/2018. Jenis penelitian ini adalah ex post facto dan teknik pengambilan sampel yang digunakan adalah teknik proportional cluster random sampling dengan sampel sebanyak 132 siswa. Pengambilan data dilakukan dengan menggunakan angket disiplin belajar, kecemasan, perhatian orang tua dan tes hasil belajar matematika. Hasil penelitian menunjukkan bahwa disiplin belajar, kecemasan dan perhatian orang tua memberikan pengaruh secara simultan terhadap hasil belajar matematika siswa kelas VIII SMP Negeri 27 Samarinda Tahun Ajaran 2017/2018 dengan sumbangan sebesar $18,1 \%$. Secara parsial disiplin belajar, kecemasan dan perhatian orang tua memberikan pengaruh terhadap hasil belajar matematika siswa kelas VIII SMP Negeri 27 Samarinda Tahun Ajaran 2017/2018.
\end{abstract}

Kata kunci: Disiplin belajar, Kecemasan, Perhatian orang tua, Hasil belajar

\begin{abstract}
Student learning outcomes are variables in education. Learning outcomes are influenced by many factors. These factors are not only internal factors, but also external factors. The purpose of this study is to study, learn, and parents to the results of learning mathematics class VIII SMP Negeri 27 Samarinda academic year 2017/2018. The type of this research is ex post facto and sampling technique which is proportional cluster random sampling technique with sample of 132 students. Data were collected using questionnaires of learning discipline, anxiety, parental attention and mathematics learning outcomes. The results showed that the discipline of learning, errors and insight of parents gave the results simultaneously to the results of learning mathematics students of class VIII SMP Negeri 27 Samarinda Academic Year 2017/2018 with a contribution of $18.1 \%$. Online learning, anxiety and insight of parents give the results of learning mathematics of students of class VIII SMP Negeri 27 Samarinda Academic Year $2017 / 2018$.
\end{abstract}

Keywords: Learning discipline, Anxiety, Parental attention, Learning outcomes 


\section{PENDAHULUAN}

Pendidikan adalah usaha sadar dan terencana untuk mewujudkan suasana belajar dan proses pembelajaran agar siswa secara aktif mengembangkan potensi dirinya untuk memiliki kekuatan spiritual keagamaan, pengendalian diri, kepribadian, kecerdasan akhlak mulia, serta keterampilan yang diperlukan dirinya, masyarakat, bangsa dan negara. Pendidikan dari waktu ke waktu tetap menjadi prioritas untuk dikembangkan agar tujuan pendidikan nasional dapat tercapai. Tujuan dan fungsi pendidikan secara umum adalah memberikan dasar yang dibutuhkan oleh siswa dalam kehidupan sehari-hari.

Setiap individu tentu pernah melakukan aktivitas belajar, karena aktivitas belajar tidak dapat dipisahkan dari kehidupan seseorang sepanjang hidupnya. Belajar adalah proses yang diarahkan kepada tujuan, proses berbuat melalui berbagai pengalaman, dan melalui suatu aktivitas yang ditunjukkan oleh perubahan tingkah laku sebagai hasil pengalaman.

Proses keberhasilan siswa dalam belajar dapat dipengaruhi oleh faktorfaktor yang digolongkan dalam faktor internal dan eksternal. Faktor internal adalah faktor yang ada dalam diri individu yang sedang belajar. Salah satunya adalah faktor psikologis yang meliputi intelligensi, minat, disiplin, bakat, kecemasan, dan motivasi. Adapun faktor eksternal adalah faktor yang ada di luar individu, seperti faktor keluarga, faktor sekolah dan masyarakat.

Matematika merupakan suatu ilmu yang mengajarkan mengenai cara menghitung suatu hal dalam penyelesaian masalah. Mata pelajaran Matematika merupakan bagian dari pendidikan formal yang memberi kontribusi dalam membekali siswa. Dalam pembelajaran matematika, tugas seorang guru tidak hanya menyajikan materi-materi saja, akan tetapi sebaiknya diintegrasikan antara satu topik dengan topik yang lainnya, bahkan dengan bidang lain. Matematika harus diperkenalkan dan disajikan ke dalam kehidupan sehari-hari.

Menurut Tu'u (2004) disiplin belajar siswa berkenaan dengan giatnya siswa dalam berusaha untuk memenuhi target serta waktu yang tepat dalam lingkup belajar. Hal tersebut mengindikasikan bahwa disiplin dalam bekerja dan disiplin waktu, terutama terkait kegiatan belajar siswa. Target belajar siswa adalah mendapatkan hasil belajar maksimal atau minimal mencapai KKM. Pencapaian hasil belajar matematika siswa kelas VIII SMP Negeri 27 Samarinda tergolong rendah. Kondisi demikian menunjukkan bahwa siswa sudah berusaha disiplin bekerja untuk mencapai target hasil belajar yang mencapai KKM, namun hasil pekerjaannya tidak sesuai target. Selain itu, hasil belajar itu menunjukkan bahwa siswa juga sudah berusaha disiplin dalam waktu ulangan harian (ujian) yang tersedia, namun belum sukses.

Menurut Arikunto (2010) disiplin adalah kepatuhan seseorang dalam mengikuti peraturan dan tata tertib karena didorong oleh adanya kesadaran yang ada pada kata hatinya. Ditambahkan juga bahwa ketertiban menunjukkan pada kepatuhan seseorang dalam mengikuti peraturan dan tata tertib karena didorong

2 Pengaruh Disiplin Belajar, Kecemasan Dan Perhatian Orang Tua Terhadap Hasil Belajar Matematika Siswa Aulia Ariski Asmawati - Sugeng - P.M. Labulan 
atau disebabkan oleh sesuatu yang datang dari luar.

Selain disiplin belajar, kecemasan juga ikut berperan dalam mempengaruhi hasil belajar matematika siswa. Menurut Munasiah (2015) Kecemasan menunjuk pada suatu suasana, perasaan, ditandai dengan rasa ketakutan terhadap bahaya atau ancaman; dan perasaan cemas itu timbul ketika seseorang mengalami tekanan perasaan (frustasi) serta ketidakmampuan menghadapi masalah. Kecemasan menunjuk pada emosi yang tidak menyenangkan, sehingga menimbulkan rasa "kekhawatiran", dan "rasa takut", dalam tingkatan yang berbeda bagi setiap individu. Berdasarkan wawancara dengan guru matematika kelas VIII SMP Negeri 27 Samarinda, hasil ulangan matematika yang rendah, menunjukkan bahwa siswa tidak mampu menyelesaikan soal matematika dengan benar, berarti siswa tidak mampu menghadapi permasalahan tentang ulangan harian, kurang penguasaan materi, sehingga pada dirinya timbul kekhawatiran akan keberhasilannya dan menjadi kenyataan memperoleh hasil rendah. Dengan demikian, rendahnya pencapaian hasil belajar matematika siswa terkait dengan adanya faktor kecemasan siswa.

Menurut Nevid \& Greene (2005) kecemasan adalah gangguan panik yang muncul secara berulang dan tidak terduga. Kecemasan ini umumnya akan menimbulkan gejala fisiologis seperti gemetar, jantung berdebar-debar, napas cepat, napas tersengal, berkeringat banyak, dan rasa lemas serta pusing tujuh keliling.
Selain disiplin belajar, perhatian orang tua juga ikut berperan dalam mempengaruhi hasil belajar matematika siswa. Perhatian orang tua terhadap belajar anak, sebagai tanggungjawab orang tua dalam membentuk dan mengatasi permasalahan yang menghambat belajar anak. Menurut Slameto (2010) bentuk perhatian orang tua dapat dilihat dari kepedulian mereka terhadap pendidikan anaknya; atau keberhasilan dan kemajuan prestasi anak dalam belajar. Berdasarkan kenyataan yang ada di SMP Negeri 27 Samarinda pencapaian hasil belajar matematika siswa adalah rendah. Oleh karenanya, rendahnya pencapaian hasil belajar ini dimungkinkan orang tua siswa kurang peduli terhadap anaknya dalam hal belajar, seperti: tidak memperhatikan anak belajar atau tidak, tidak memperhatikan kebutuhan anak dalam belajar, tidak mau tahu kemajuan belajar anak, bahkan kesulitan yang dialami anak dalam belajar

Perhatian adalah pemusatan atau konsentrasi dari seluruh aktivitas individu yang ditujukan kepada suatu obyek atau kepada sekumpulan obyek-obyek. Perhatian merupakan penyeleksian terhadap stimuli yang diterima oleh individu yang bersangkutan. Perhatian dapat didefinisikan sebagai proses pemusatan phase-phase atau unsur-unsur pengalaman dan mengabaikan yang lainnya. Perhatian orang tua adalah suatu aktivitas psikis yang diberikan orang tua terhadap anak secara khusus terhadap proses dan hasil belajar anak dalam bentuk usaha dan sikap yang dapat mendorong dan meningkatkan prestasi anak. 
Berdasarkan sejumlah identifikasi masalah di atas, penelitian ini bertujuan untuk mengetahui pengaruh disiplin belajar, kecemasan dan perhatian orang tua secara simultan terhadap hasil belajar matematika siswa kelas VIII SMP Negeri 27 Samarinda tahun ajaran 2017/2018. Penelitian ini juga bertujuan untuk mengetahui pengaruh disiplin belajar, kecemasan dan perhatian orang tua secara parsial terhadap hasil belajar matematika siswa kelas VIII SMP Negeri 27 Samarinda tahun ajaran 2017/2018.

\section{METODE PENELITIAN}

Penelitian ini dilakukan dengan pendekatan ex post facto, yaitu penelitian setelah kejadian. Pada penelitian ini terdiri atas empat variabel, yaitu 3 variabel bebas, dan 1 variabel terikat. Variabel bebas pada penelitian ini adalah disiplin belajar yang dilambangkan dengan $\left(\mathrm{X}_{1}\right)$, kecemasan yang dilambangkan dengan $\left(\mathrm{X}_{2}\right)$, dan perhatian orang tua yang dilambangkan dengan $\left(\mathrm{X}_{3}\right)$, dan variabel terikat pada penelitian ini adalah hasil belajar matematika yang dilambangkan dengan (Y). Untuk melihat pengaruh antara variabel bebas terhadap variabel terikat pada penelitian ini dibuat rancangan penelitian. Model rancangan penelitian ini disajikan melalui Gambar 1 dan Gambar 2.

Penelitian ini dilaksanakan pada siswa kelas VIII di SMP Negeri 27 Samarinda yang bertempat di Jalan Batu Cermin RT. 04, Sempaja Utara, Kota Samarinda, tahun pembelajaran 2017/2018 semester genap pada bulan April. Populasi yang digunakan dalam penelitian ini sebanyak 198 siswa dan diperoleh jumlah sampel 132 siswa.
Teknik sampling yang digunakan dalam penelitian ini adalah Proportional Cluster Random Sampling, yaitu pengambilan anggota sampel dari populasi acak dan proporsional.

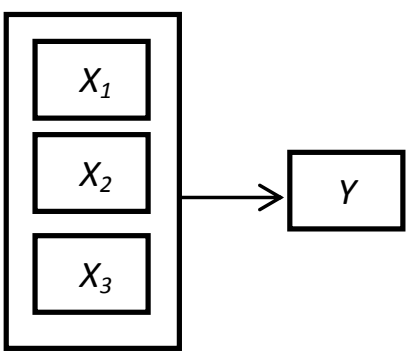

Gambar 1. Model rancangan penelitian secara simultan

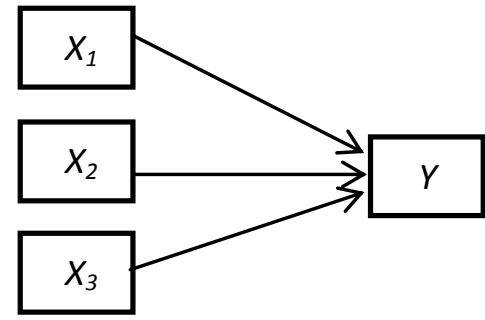

Gambar 2. Model rancangan penelitian secara parsial

Teknik pengumpulan data yang digunakan berupa angket dan tes. Angket digunakan untuk memperoleh data disiplin belajar, kecemasan dan perhatian orang tua. Tes digunakan untuk memperoleh data hasil belajar matematika siswa.

Indikator disiplin belajar terdiri dari ketaatan terhadap tata tertib sekolah, ketaatan terhadap kegiatan belajar di sekolah, ketaatan dalam mengerjakan tugas-tugas pelajaran dan ketaatan terhadap kegiatan belajar di rumah yang berguna untuk mengukur tingkat disiplin belajar siswa kelas VIII SMP Negeri 27 Samarinda. Indikator kecemasan terdiri dari gangguan behavior, gangguan 
kognitif, gangguan fisiologis dan gangguan sosial yang berguna untuk mengukur tingkat kecemasan siswa kelas VIII SMP Negeri 27 Samarinda. Indikator perhatian orang tua terdiri dari tanggung jawab, relasi di rumah dan keluarga, memotivasi dalam belajar, pengisian waktu luang dan kebiasaan belajar anak yang berguna untuk mengukur tingkat perhatian orang tua siswa kelas VIII SMP Negeri 27 Samarinda.

Sebelum melakukan penelitian, peneliti melakukan uji coba butir angket disiplin belajar, kecemasan, dan perhatian orang tua, serta uji coba butir soal tes hasil belajar untuk dapat menentukan validitas dan reliabilitas dari seluruh butir soal tersebut. Uji coba dilakukan di SMP Negeri 27 Samarinda kelas VIII B yang bukan termasuk sampel dan dipilih secara acak yang berjumlah 33 siswa. Pada angket disiplin belajar, dari 40 butir pernyataan yang diujicobakan terdapat 7 butir pernyataan yang tidak valid, sehingga ada 33 butir pernyataan yang digunakan untuk penelitian. Angket kecemasan, dari 40 butir pernyataan yang diujicobakan terdapat 8 butir pernyataan yang tidak valid, sehingga ada 32 butir pernyataan yang digunakan untuk penelitian. Pada angket perhatian orang tua, dari 40 butir pernyataan yang diujicobakan terdapat 10 butir pernyataan yang tidak valid, sehingga ada 30 butir pernyataan yang digunakan untuk penelitian. Untuk tes hasil belajar matematika diujicobakan untuk mengetahui indeks kesukaran dan indeks pembeda tiap butir soal, serta reliabilitasnya.
Teknik analisis data yang digunakan adalah statistik deskriptif dan statistik inferensial. Penyajian distribusi skor dan pengkategorian dari masing-masing variabel bebas dengan interpretasi skor yang dirumuskan oleh Sugiyono (2010) seperti pada Tabel 1, dengan $\mu$ menyatakan rata-rata variabel, sedangkan $\sigma$ menyatakan standar deviasi.

Tabel 1. Kategori Rumusan Distribusi Skor Untuk Angket

\begin{tabular}{cl}
\hline Skor & Kategori \\
\hline$X \leq \mu-1,5(\sigma)$ & sangat \\
& rendah \\
$\mu-1,5(\sigma)<X \leq \mu-0,5(\sigma)$ & Rendah \\
$\mu-0,5(\sigma)<X \leq \mu+0,5(\sigma)$ & Sedang \\
$\mu+0,5(\sigma)<X \leq \mu+1,5(\sigma)$ & Tinggi \\
$\mu+1,5(\sigma)<X$ & sangat \\
& tinggi \\
\hline
\end{tabular}

Berdasarkan pengkategorian pada Tabel 1, distribusi skor dan pengkategorian dari variabel disiplin belajar siswa dalam penelitian ini, tampak pada Tabel 2.

Tabel 2. Kategori Interval Skor Disiplin Belajar

\begin{tabular}{cc}
\hline Interval & Kategori \\
$X \leq 83$ & Sangat Rendah \\
$83<X \leq 93$ & Rendah \\
$93<X \leq 102$ & Sedang \\
$102<X \leq 112$ & Tinggi \\
$X>112$ & Sangat Tinggi \\
\hline
\end{tabular}

Untuk distribusi dan pengkategorian skor untuk variabel kecemasan dapat dilihat pada Tabel 3. 
Tabel 3. Kategori Interval Skor Kecemasan

\begin{tabular}{cc} 
Interval & Kategori \\
$X \leq 63$ & Sangat Rendah \\
$63<X \leq 75$ & Rendah \\
$75<X \leq 87$ & Sedang \\
$87<X \leq 98$ & Tinggi \\
$X>98$ & Sangat Tinggi \\
\hline
\end{tabular}

Untuk distribusi dan pengkategorian skor untuk variabel perhatian orang tua dapat dilihat pada Tabel 4 .

Tabel 4. Kategori Interval Skor Perhatian Orang Tua

\begin{tabular}{cc}
\hline Interval & Kategori \\
$X \leq 72$ & Sangat Rendah \\
$72<X \leq 82$ & Rendah \\
$82<X \leq 92$ & Sedang \\
$92<X \leq 102$ & Tinggi \\
$X>102$ & Sangat Tinggi \\
\hline
\end{tabular}

Untuk mengetahui kecenderungan hasil pengamatan tes hasil belajar maka dikelompokkan menjadi lima kategori seperti pada Tabel 5 .

Tabel 5. Kriteria Kategori Interval Skor Hasil Belajar Matematika

\begin{tabular}{cc}
\hline Interval & Kategori \\
$X \leq 14$ & Sangat Rendah \\
$14<X \leq 35$ & Rendah \\
$35<X \leq 57$ & Sedang \\
$57<X \leq 78$ & Tinggi \\
$78<X \leq 100$ & Sangat Tinggi
\end{tabular}

Sebelum melakukan pengujian hipotesis terlebih dahulu dilakukan beberapa pemeriksaan asumsi-asumsi yang harus dipenuhi yaitu uji normalitas, uji heteroskedastisitas, uji linieritas dan uji multikolonieritas.

Pada pengujian hipotesis akan dilihat apakah ada pengaruh ketiga variabel bebas secara bersama-sama terhadap variabel terikat. Pengujian selanjutnya akan dilihat apakah ada pengaruh masing-masing variabel bebas terhadap varibel terikat secara parsial. Taraf signifikansi yang digunakan untuk menguji hipotesis penelitian sebesar $5 \%$ atau 0,05 .

\section{HASIL PENELITIAN DAN PEMBA- HASAN}

Berdasarkan hasil penelitian, diperoleh data tentang disiplin belajar $\left(\mathrm{X}_{1}\right)$, kecemasan $\left(\mathrm{X}_{2}\right)$, dan perhatian orang tua $\left(\mathrm{X}_{3}\right)$, serta hasil belajar matematika (Y). Adapun deskriptif data dari keempat variabel ini dapat dilihat pada Tabel 6 .

Tabel 6. Deskriptif Data

\begin{tabular}{crrrr}
\hline Variabel & Min & Maks & Mean & \multicolumn{1}{c}{ Std } \\
\hline $\mathrm{X}_{1}$ & 70 & 130 & 97,50 & 9,98 \\
$\mathrm{X}_{2}$ & 51 & 120 & 80,77 & 11,75 \\
$\mathrm{X}_{3}$ & 58 & 112 & 86,94 & 9,73 \\
$\mathrm{Y}$ & 5 & 94 & 46,10 & 21,47 \\
\hline
\end{tabular}

Distribusi frekuensi untuk variabel disiplin belajar disajikan ke dalam Tabel 7. Terlihat disiplin belajar siswa bervariasi mulai dari kategori sangat rendah sampai dengan kategori sangat tinggi, dan persentase terbesar pada kategori sedang, yaitu 37,88\%. Secara keseluruhan terkait variabel disiplin, terlihat bahwa siswa memiliki disiplin belajar pada kategori sedang. Berarti, distribusi presentase ini mendukung statistik deskriptif bahwa disiplin belajar 
siswa termasuk kategori sedang.

Tabel 7. Distribusi Frekuensi Skor Variabel Disiplin Belajar

\begin{tabular}{cccc}
\hline \multicolumn{2}{c}{ Skor Disiplin Belajar } & Frekuensi & Persentase (\%) \\
Interval & Kategori & 8 & 6,06 \\
\hline$X \leq 83$ & Sangat Rendah & 36 & 27,27 \\
$83<X \leq 93$ & Rendah & 50 & 37,88 \\
$93<X \leq 102$ & Sedang & 29 & 21,97 \\
$102<X \leq 112$ & Tinggi & 9 & 6,82 \\
$X>112$ & Sangat Tinggi & 132 & 100 \\
\hline
\end{tabular}

Tabel 8. Distribusi Frekuensi Skor Variabel Kecemasan Siswa

\begin{tabular}{cccc}
\hline \multicolumn{2}{c}{ Skor Kecemasan Siswa } & Frekuensi & Persentase $(\%)$ \\
Interval & Kategori & 9 & 6,82 \\
$X \leq 63$ & Sangat Rendah & 34 & 25,76 \\
$63<X \leq 75$ & Rendah & 53 & 40,15 \\
$75<X \leq 87$ & Sedang & 29 & 21,97 \\
$87<X \leq 98$ & Tinggi & 7 & 5,30 \\
$X>98$ & Sangat Tinggi & 132 & 100 \\
\hline
\end{tabular}

Tabel 9. Distribusi Frekuensi Skor Variabel Perhatian Orang Tua Siswa

\begin{tabular}{cccc}
\hline \multicolumn{2}{c}{ Skor Perhatian Orang Tua } & Frekuensi & Persentase (\%) \\
Interval & Kategori & 7 & 5,30 \\
\hline$X \leq 72$ & Sangat Rendah & 39 & 29,55 \\
$72<X \leq 82$ & Rendah & 50 & 37,88 \\
$82<X \leq 92$ & Sedang & 29 & 21,97 \\
$92<X \leq 102$ & Tinggi & 7 & 5,30 \\
$X>102$ & Sangat Tinggi & 132 & 100 \\
\hline
\end{tabular}

Tabel 10. Distribusi Frekuensi Skor Variabel Hasil Belajar Matematika

\begin{tabular}{cccc}
\hline \multicolumn{2}{c}{ Skor Hasil Belajar } & Frekuensi & Persentase (\%) \\
Interval & Kategori & & 7,57 \\
$X \leq 14$ & Sangat Rendah & 10 & 25,52 \\
$14<X \leq 35$ & Rendah & 35 & 35,61 \\
$35<X \leq 57$ & Sedang & 47 & 20,45 \\
$57<X \leq 78$ & Tinggi & 27 & 9,85 \\
$78<X \leq 100$ & Sangat Tinggi & 13 & 100 \\
\hline
\end{tabular}


Distribusi frekuensi untuk variabel kecemasan siswa disajikan ke dalam Tabel 8. Berdasarkan tabel distribusi tersebut, terlihat bahwa kecemasan siswa bervariasi mulai dari kategori sangat rendah sampai dengan kategori sangat tinggi, dan persentase terbesar terletak pada kategori sedang, yaitu $40,15 \%$. Secara keseluruhan terkait variabel kecemasan, terlihat siswa memiliki kecemasan dengan kategori sedang. Dengan demikian, distribusi presentase ini mendukung statistik deskriptif bahwa kecemasan siswa termasuk kategori sedang.

Distribusi frekuensi untuk variabel perhatian orang tua disajikan ke dalam Tabel 9. Berdasarkan tabel distribusi di atas, terlihat bahwa perhatian orang tua siswa bervariasi mulai dari kategori sangat rendah sampai dengan kategori sangat tinggi, dan persentase terbesar terletak pada kategori sedang, yaitu $37,88 \%$. Secara keseluruhan terkait variabel perhatian orang tua, terlihat bahwa perhatian orang tua siswa termasuk kategori sedang. Dengan demi-kian, distribusi presentase ini mendukung statistik deskriptif bahwa perhatian orang tua siswa termasuk kategori sedang.

Distribusi frekuensi untuk variabel hasil belajar disajikan ke dalam Tabel 10. Berdasarkan tabel distribusi tersebut, terlihat bahwa hasil belajar matematika siswa bervariasi mulai dari kategori sangat rendah sampai dengan kategori sangat tinggi, dan persentase terbesar adalah kategori sedang, yaitu $35,61 \%$. Secara keseluruhan dalam penelitian ini terlihat bahwa siswa memiliki hasil belajar matematika pada kategori sedang. Dengan demikian, disribusi persentase ini mendukung statistik deskriptif bahwa hasil belajar matematika siswa termasuk kategori sedang.

Berdasarkan hasil uji normalitas diperoleh nilai signifikansi pada Tabel 11 . Berdasarkan Tabel 11, diperoleh kesimpulan bahwa variabel disiplin belajar, variabel kecemasan, variabel perhatian orang tua, dan variabel hasil belajar matematika berasal dari populasi yang berdistribusi normal. Karena memiliki nilai Sig. $>0.05$.

Tabel 11. Hasil Uji Normalitas

\begin{tabular}{ll}
\hline Variabel & Sig. \\
\hline Disiplin Belajar & 0,624 \\
Kecemasan & 0,921 \\
Perhatian Orang Tua & 0,345 \\
Hasil Belajar Matematika & 0,822 \\
\hline
\end{tabular}

Berdasarkan Scatter Plot Dependent Variable menghasilkan bentuk pola diagram pencar seperti pada Gambar 2. Dapat dilihat bahwa hasil plot residual terhadap variabel terikat yaitu hasil belajar matematika menghasilkan pola diagram pencar yang tidak membentuk suatu pola tertentu sehingga data yang digunakan pada penelitian ini bersifat homogen.

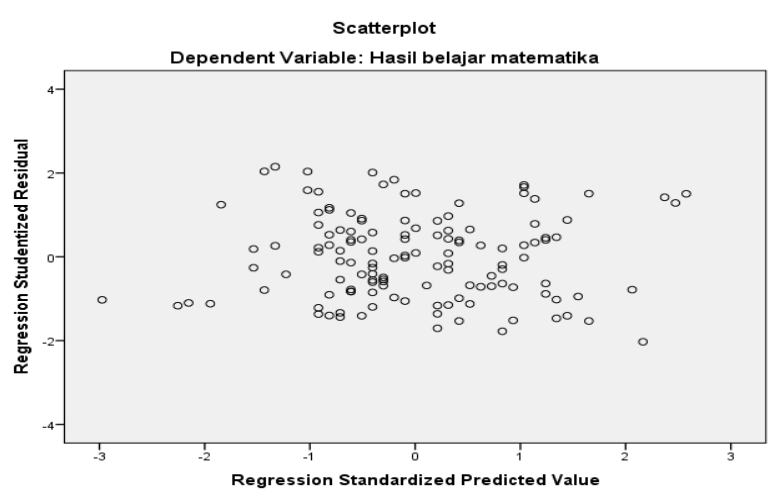

Gambar 2. Hasil pemeriksaan heteroskedastisitas data 
Untuk menggunakan analisis regresi linear ganda maka model yang telah ditentukan harus bersifat linier. Variabel disiplin belajar, variabel kecemasan, dan variabel perhatian orang tua dapat digunakan untuk mencari pengaruh terhadap hasil belajar matematika pada penelitian ini. Hal ini dikarenakan nilai signifikansi linearity untuk masingmasing variabel adalah sebesar 0,000 atau kurang dari 0,05.

Berdasarkan hasil perhitungan dengan melihat nilai tolerance dan Variance inflation factor (VIF) diperoleh hasil perhitungan seperti pada Tabel 12 . Berdasarkan tabel tersebut masing-masing variabel mempunyai nilai. Karena nilai tolerance lebih dari 0,1 dan nilai VIF kurang dari 10 maka dapat disimpulkan bahwa tidak terjadi multikolinieritas antara ketiga variabel bebas.

Tabel 12. Hasil Perhitungan

\begin{tabular}{lll}
\multicolumn{3}{c}{ Multikolinieritas } \\
\hline Variabel & Tolerance & VIF \\
\hline Disiplin belajar & 0,706 & 1,416 \\
Kecemasan & 0,865 & 1,156 \\
Perhatian orang tua & 0,750 & 1,333
\end{tabular}

Untuk menguji hipotesis ini digunakan analisis regresi ganda dengan menepatkan hasil belajar matematika sebagai variabel terikat dan disiplin belajar, lingkungan sosial, variasi gaya mengajar guru sebagai variabel bebas. Hasil analisis regresi linier ganda dapat dilihat pada Tabel 13. Berdasarkan Tabel 13, diperoleh nilai signifikansi $0,000<0,005$ dan berdasarkan Kriteria keputusan, H0 ditolak sehingga dapat disimpulkan bahwa ada pengaruh yang signifikan antara disiplin belajar, kecemasan dan perhatian orang tua terhadap hasil belajar matematika siswa kelas VIII SMP Neggeri 27 Samarinda tahun ajaran 2017/2018. Daya ramal model ditunjukkan oleh koefisien determinasi $\left(\mathrm{R}^{2}\right)$ sebesar 0,181 yang berarti bahwa $18,1 \%$ variasi nilai variabel terikat dapat dijelaskan oleh model. Hal ini berarti bahwa variabel disiplin belajar, kecemasan dan perhatian orang tua mempengaruhi hasil belajar matematika sebesar $18,1 \%$ dan yang sisanya sebesar $81,9 \%$ dipengaruhi oleh faktor lainnya yang tidak diungkapkan dalam penelitian ini.

Berdasarkan Tabel 14, diperoleh model regresi linier berganda berikut: $\hat{Y}=-56,734+0,431 X_{1}+0,313 X_{2}+0,409 X_{3}$ Berdasarkan Tabel 14 diperoleh koefisien determinasi parsial $\left(\mathrm{r}^{2}\right)$ untuk variabel disiplin belajar sebesar 0,123 yang berarti hasil belajar matematika siswa dipengaruhi oleh disiplin belajar sebesar $12,3 \%$, koefisien determinasi parsial $\left(\mathrm{r}^{2}\right)$ untuk variabel kecemasan sebesar 0,085 yang berarti hasil belajar matematika siswa dipengaruhi oleh lingkungan sosial sebesar 8,5\%, koefisien determinasi parsial $\left(\mathrm{r}^{2}\right)$ untuk variabel perhatian orang tua sebesar 0,108 yang berarti hasil

Tabel 13. Tabel Anova

\begin{tabular}{cccccc}
\hline Model & Sum of Squares & Df & Mean Square & F & Sig. \\
\hline Regression & 10936,646 & 3 & 3645,549 & 9,433 & $.000^{\mathrm{b}}$ \\
Residual & 49469,074 & 128 & 386,477 & & \\
Total & 60405,720 & 131 & & & \\
\hline
\end{tabular}


Tabel 14. Hasil Uji Signifikansi Variabel Bebas Secara Parsial

\begin{tabular}{cccccc}
\hline Variable & Rata-rata & $\begin{array}{c}\text { Koefisien } \\
\text { regresi }\end{array}$ & $t_{\text {hit }}$ & Sig. & $\begin{array}{c}\text { Koef. } \\
\text { determinasi } \\
\text { parsial }\end{array}$ \\
\hline Konstanta & & $-56,734$ & $-2,908$ & 0,004 & \\
$\mathrm{X}_{1}$ & 97,50 & 0,431 & 2,103 & 0,037 & 0,123 \\
$\mathrm{X}_{2}$ & 80,77 & 0,313 & 1,993 & 0,048 & 0,085 \\
$\mathrm{X}_{3}$ & 86,94 & 0,409 & 2,005 & 0,047 & 0,108 \\
\hline
\end{tabular}

belajar matematika siswa dipengaruhi oleh perhatian orang tua sebesar $10,8 \%$.

Hasil penelitian dan analisis data menunjukkan bahwa hasil belajar matematika siswa pada materi lingkaran akan meningkat apabila disiplin belajar, kecemasan dan perhatian orang tua siswa semakin tinggi. Begitu pula sebaliknya, jika disiplin belajar, kecemasan, dan perhatian orang tua rendah maka hasil belajar matematika yang dicapai siswa juga rendah. Kondisi demikian, dapat dikatakan bahwa disiplin belajar, kecemasan, dan perhatian orang tua memiliki pengaruh yang berarti terhadap hasil belajar matematika siswa, terutama pada materi Lingkaran.

\section{KESIMPULAN}

1. Terdapat pengaruh secara simultan antara disiplin belajar, kecemasan, dan perhatian orang tua terhadap hasil belajar matematika siswa kelas VIII SMP Negeri 27 Samarinda tahun ajaran 2017/2018; serta memberikan kontribusi terhadap hasil belajar matematika sebesar $18,1 \%$.

2. Terdapat pengaruh secara parsial antara disiplin belajar, kecemasan, dan perhatian orang tua terhadap hasil belajar matematika siswa kelas VIII SMP Negeri 27 Samarinda tahun ajaran 2017/2018.

\section{DAFTAR PUSTAKA}

Tu'u, T. (2004). Peran Disiplin Pada Perilaku dan Prestasi Siswa. Jakarta: Grasindo.

Arikunto, S. (2010). Dasar-dasar Evaluasi Pendidikan Edisi Revisi. Jakarta: Bumi Aksara.

Munasiah. (2015). Pengaruh Kecemasan Belajar dan Pemahaman Konsep Matematika Siswa terhadap Kemampuan Penalaran Matematika. Jurnal Formatif, 5(3), hal. 220-232, 2015, ISSN: 2088-351X.

Nevid, J., \& Greene, B. (2005). Psikologi Abnormal. Terjemahan oleh Tim Fakultas Psikologis Universitas Indonesia. Jakarta: Erlangga.

Slameto. 2010. Belajar dan Faktor-faktor yang Mempengaruhinya. Jakarta: Rineka Cipta.

Sukardi. 2004. Metodologi Penelitian Pendidikan. Jakarta: Bumi Aksara.

Azwar, S. 1995. Sikap Manusia. Yogyakarta: Pustaka Belajar.

Sugiyono. 2010. Statistika untuk Penelitian. Bandung: CV. Alfabeta. 